\title{
Effects of postbiotic supplementation on growth performance, ruminal fermentation and microbial profile, blood metabolite and GHR, IGF-1 and MCT-1 gene expression in post-weaning lambs
}

\author{
Wan Ibrahim Izuddin', Teck Chwen Loh ${ }^{1,2^{*}}$ (D), Anjas Asmara Samsudin ${ }^{1,2}$, Hooi Ling Foo ${ }^{3,4^{*}}$, \\ Ali Merzza Humam ${ }^{1,5}$ and Nurhazirah Shazali ${ }^{1}$
}

\begin{abstract}
Background: Postbiotics have been established as potential feed additive to be used in monogastric such as poultry and swine to enhance health and growth performance. However, information on the postbiotics as feed additive in ruminants is very limited. The aim of this study was to elucidate the effects of supplementation of postbiotics in newly-weaned lambs on growth performance, digestibility, rumen fermentation characteristics and microbial population, blood metabolite and expression of genes related to growth and volatile fatty acid transport across the rumen epithelium.
\end{abstract}

Results: Postbiotic supplementation increased weight gain, feed intake, nutrient intake and nutrient digestibility of the lambs. No effect on ruminal pH and total VFA, whereas butyrate and ruminal ammonia- $\mathrm{N}$ concentration were improved. The lambs fed with postbiotics had higher blood total protein, urea nitrogen and glucose. However, no difference was observed in blood triglycerides and cholesterol levels. Postbiotics increased the population of fibre degrading bacteria but decreased total protozoa and methanogens in rumen. Postbiotics increased the mRNA expression of hepatic IGF-1 and ruminal MCT-1.

Conclusions: The inclusion of postbiotics from L. plantarum RG14 in newly-weaned lambs improved growth performance, nutrient intake and nutrient digestibility reflected from better rumen fermentation and microbial parameters, blood metabolites and upregulation of growth and nutrient intake genes in the post-weaning lambs.

Keywords: Postbiotics, Lactobacillus plantarum, Growth performance, Rumen fermentation, Blood metabolite, Gene expression, Nutrient uptake, Post-weaning lambs

\section{Background}

In sheep production, weaning process is recognized as one of the stressful procedures which is influenced by environment, nutrition and psychology that potentially affect the growth performance and health of the lambs $[1,2]$.

\footnotetext{
* Correspondence: tcloh@upm.edu.my; hlfoo@upm.edu.my

${ }^{1}$ Department of Animal Science, Faculty of Agriculture, Universiti Putra Malaysia, 43400 Serdang, Selangor, Malaysia

${ }^{3}$ Department of Bioprocess Technology, Faculty of Biotechnology and Biomolecular Sciences, Universiti Putra Malaysia, 43400 Serdang, Selangor, Malaysia

Full list of author information is available at the end of the article
}

Weaning stress contributes to a reduction in feed intake and therefore decrease growth rate and increase the vulnerability to diseases. These circumstances could affect the growth performance of lambs in the post-weaning period. Thus, good weaning management including nutritional modification is essential in alleviating the stress and improving health and performance at the post-weaning period. In ruminants, bacterial and yeast probiotics are being utilized as feed additives to generally enhance rumen fermentation and promote immune function and general health [3]. Probiotics in the rumen interact with rumen

(c) The Author(s). 2019 Open Access This article is distributed under the terms of the Creative Commons Attribution 4.0 International License (http://creativecommons.org/licenses/by/4.0/), which permits unrestricted use, distribution, and reproduction in any medium, provided you give appropriate credit to the original author(s) and the source, provide a link to the Creative Commons license, and indicate if changes were made. The Creative Commons Public Domain Dedication waiver (http://creativecommons.org/publicdomain/zero/1.0/) applies to the data made available in this article, unless otherwise stated. 
microbes to enhance rumen fermentation and synthesis of antimicrobial substances such as bacteriocins that inhibit the harmful pathogens in the gut [4]. Probiotic use in ruminants may contribute to beneficial effects in term of enhancing population of ruminal cellulolytic bacteria [5] leading to greater fibre digestibility, improving synthesis and bio-availability of nutrients contributing to a better growth performance [6]. The increment of feed intake, nutrient absorption, feed conversion ratio (FCR) leading to greater production performance $[7,8]$. It has been reported that probiotics are used widely as feed supplement and may contributes better health and growth performance for the weaned lamb. However, probiotics are sensitive to environmental condition i.e. sun-light, $\mathrm{pH}$ of water. Thus, they need a proper and careful handling and offering to the weaned lamb. Consequently, it creates cumbersome to farmers in terms of application. Likewise, some probiotics may carry antibioticresistant genes, particularly bacteria with plasmidencoded which able to transfer between organisms $[9,10]$. The gene could transfer from probiotics to native microbes and potentially transfer to pathogens.

Thus, postbiotics are proposed to be an alternative as feed supplement due to ease of handling and application. Postbiotics are the metabolites of probiotic bacteria which are characterized by probiotic effect with the absence of living cells. Addition of postbiotics in the diets have been shown to improve growth performance in the monogastric animals such as broilers [11, 12], layers [13] and piglets $[14,15]$. Presence of antimicrobial metabolites such as organic acids and bacteriocins in the postbiotics have been shown to exhibit high inhibitory activity against pathogenic bacteria such as Salmonella typhimurium, Escherichia coli, Listeria monocytogenes, Pediococcus acidilactici and Vancomycin-resistant Enterococci (VRE) [16, 17]. However, postbiotics as feed additive were not investigated in ruminants particularly on its effect on rumen fermentation and feed utilization efficiency. Thus, the objective of this study was to elucidate the effects of postbiotics from Lactobacillus plantarum RG14 on growth performance focusing on rumen fermentation characteristics and nutrient utilization in the post-weaning lambs. Therefore, the response of the postbiotics on rumen fermentation profiles and microbial population, nutrient intake and digestibility, blood metabolites and expression of genes related to growth and ruminal nutrients transporter were examined to improve the understanding of the postbiotic action in ruminants. The postbiotics from L. plantarum RG14 was chosen as this strain give highest cell population and inhibitory activity against several pathogenic microorganisms [18].

\section{Results}

\section{Growth performance, nutrient intake and apparent digestibility}

The postbiotic supplementation significantly increased $(P<0.05)$ final weight gain, total weight gain, average daily gain (ADG) (Table 1$)$. No differences $(P>0.05)$ were found in total feed intake, daily feed intake and FCR.

\section{Nutrient intake and apparent digestibility}

The inclusion of postbiotics increased $(P<0.05)$ the DM, OM and NDF intake of the lambs (Table 2). No differences $(P>$ 0.05) in the $\mathrm{EE}$ and $\mathrm{CP}$ intake of lambs. In terms of nutrient digestibility, lambs received postbiotics had higher $(P<0.05)$ digestibility of DM, CP and NDF. No differences $(P>0.05)$ in the $\mathrm{OM}$ and $\mathrm{EE}$ digestibility between two groups.

\section{Rumen fermentation characteristics}

No differences $(P>0.05)$ in $\mathrm{pH}$, total and individual VFA except in the propionic acid in which postbiotic inclusion increased $(P<0.05)$ the concentration of the propionic acid in the rumen fluid (Table 3 ). Concentration of ruminal $\mathrm{NH}_{3}-\mathrm{N}$ significantly increased $(P<0.05)$ in the postbiotic group compared to the control group.

\section{Blood metabolites}

The lambs received postbiotic supplementation in the diet had higher $(P<0.05)$ total protein, urea nitrogen and glucose concentration in the blood (Table 4). No significant differences $(P>0.05)$ were recorded in blood triglycerides and cholesterol in both groups.

\section{Rumen microbial population}

There was no significant difference $(P>0.05)$ in ruminal total bacteria in the lambs fed with and without postbiotics (Table 5). In the lambs receiving postbiotics, the population of two major fibre degrading bacteria which are $F$. succinogenes and $R$. flavefaciens were higher $(P<0.05)$ but no difference $(P>0.05)$ in

Table 1 Growth performance characteristics in post-weaning lambs supplemented with and without postbiotics

\begin{tabular}{lllll}
\hline Parameters & Control & Postbiotic & SEM & $P$-value \\
\hline Initial weight $(\mathrm{kg})$ & 17.10 & 18.90 & 0.52 & 0.09 \\
Final weight $(\mathrm{kg})$ & $25.60^{\mathrm{a}}$ & $28.27^{\mathrm{b}}$ & 0.65 & 0.03 \\
Weight gain $(\mathrm{kg})$ & $8.35^{\mathrm{a}}$ & $9.37^{\mathrm{b}}$ & 0.27 & 0.04 \\
ADG (g/d) & $185.56^{\mathrm{a}}$ & $208.15^{\mathrm{b}}$ & 5.95 & 0.04 \\
Total feed intake (kg DMI) & 30.02 & 31.13 & 0.35 & 0.13 \\
Daily feed intake (kg DMI/d) & 0.67 & 0.67 & 0.001 & 0.13 \\
FCR (kg DMI/kg gain) & 3.56 & 3.33 & 0.07 & 0.01 \\
\hline
\end{tabular}

$A D G$ Average daily gain, $D M I$ Dry matter intake, $F C R$ Feed conversion ratio. ${ }^{\text {a,b }}$ Different superscripts in each row are significantly different $(P<0.05)$. Experimental unit, $(n=6)$ 
Table 2 Nutrient intake and apparent digestibility in postweaning lambs supplemented with and without postbiotics

\begin{tabular}{ccccc}
\hline Parameters & Control & Postbiotic & SEM & $P$-value \\
\hline Nutrient intake & $(\mathrm{g} \mathrm{DM} / \mathrm{d})$ & & & \\
$\mathrm{DM}$ & $481.30^{\mathrm{a}}$ & $493.80^{\mathrm{b}}$ & 3.21 & 0.03 \\
OM & $443.60^{\mathrm{a}}$ & $461.40^{\mathrm{b}}$ & 4.16 & 0.02 \\
$\mathrm{EE}$ & 17.89 & 18.27 & 0.15 & 0.25 \\
$\mathrm{CP}$ & 114.38 & 115.88 & 0.85 & 0.42 \\
NDF & $396.86^{\mathrm{a}}$ & $408.60^{\mathrm{b}}$ & 3.37 & 0.08 \\
Apparent nutrient digestibility & $(\mathrm{g} / \mathrm{kg} \mathrm{DM})$ & & \\
DM & $635.57^{\mathrm{a}}$ & $719.03^{\mathrm{a}}$ & 2.09 & 0.04 \\
OM & 729.56 & 776.00 & 1.36 & 0.09 \\
EE & 46.61 & 48.27 & 1.45 & 0.62 \\
CP & $673.48^{\mathrm{a}}$ & $733.27^{\mathrm{a}}$ & 1.35 & 0.01 \\
NDF & $386.11^{\mathrm{a}}$ & $432.69^{\mathrm{a}}$ & 0.99 & 0.01 \\
\hline DM &
\end{tabular}

$D M$ Dry matter, OM Organic matter, EE Ether extract, CP Crude protein, NDF Neutral detergent fibre. ${ }^{\mathrm{a}, \mathrm{b}}$ Different superscripts in each row are significantly different $(P<0.05)$. Experimental unit, $(n=6)$

population of $R$. albus. No difference $(P>0.05)$ in the population of protozoa between control and postbiotic groups. The reduction $(P<0.05)$ of population of the methanogens was observed in lambs receiving supplementary postbiotics in the feed.

\section{Gene expression}

No significant difference $(P>0.05)$ was observed in the expression of GHR gene between two groups (Fig. 1). Inclusion of postbiotics in the diet of lambs highly upregulated $(P<0.05)$ the hepatic expression of IGF-1 and ruminal expression of MCT-1 genes.

Table 3 Rumen fermentation characteristics in post-weaning lambs supplemented with and without postbiotics

\begin{tabular}{lllll}
\hline Parameters & Control & Postbiotic & SEM & $P$-value \\
\hline $\mathrm{pH}$ & 5.55 & 5.53 & 0.03 & 0.82 \\
$\mathrm{NH}_{3}-\mathrm{N},(\mathrm{ppm})$ & $1.46^{\mathrm{a}}$ & $2.00^{\mathrm{b}}$ & 0.14 & 0.04 \\
Volatile fatty acids $(\mathrm{VFA}), \mathrm{mM}$ & & & \\
Acetic acid (A) & 84.82 & 82.70 & 2.15 & 0.63 \\
Propionic acid (P) & $31.81^{\mathrm{a}}$ & $37.56^{\mathrm{b}}$ & 1.65 & 0.03 \\
Butyric acid & 9.30 & 9.31 & 0.37 & 1.00 \\
iso-butyric acid & 1.28 & 1.35 & 0.04 & 0.37 \\
Valeric acid & 1.18 & 1.15 & 0.06 & 0.89 \\
iso-valeric acid & 2.55 & 2.60 & 0.15 & 0.86 \\
Total VFA & 130.98 & 134.64 & 2.00 & 0.40 \\
A:P & 2.43 & 2.17 & 0.09 & 0.17 \\
\hline VFA Volatile fatty acids. & a,b & Different superscripts in each row are significantly \\
different $(P<0.05)$. Experimental unit, $(n=6)$ & &
\end{tabular}

Table 4 Blood metabolites in post-weaning lambs supplemented with and without postbiotics

\begin{tabular}{lllll}
\hline Parameters & Control & Postbiotic & SEM & $P$-value \\
\hline Total protein $(\mathrm{g} / \mathrm{L})$ & $63.60^{\mathrm{a}}$ & $98.97^{\mathrm{b}}$ & 7.16 & 0.01 \\
BUN $(\mathrm{mmol} / \mathrm{L})$ & $6.03^{\mathrm{a}}$ & $10.04^{\mathrm{b}}$ & 0.88 & 0.01 \\
Glucose $(\mathrm{mmol} / \mathrm{L})$ & $4.47^{\mathrm{a}}$ & $6.05^{\mathrm{b}}$ & 0.34 & 0.01 \\
Triglycerides $(\mathrm{mmol} / \mathrm{L})$ & 0.30 & 0.43 & 0.06 & 0.34 \\
Cholesterol $(\mathrm{mmol} / \mathrm{L})$ & 1.83 & 1.60 & 0.01 & 0.28 \\
\hline $\begin{array}{l}\text { BUN Blood urea nitrogen. } \\
\text { different }(P<0.05) \text {. Experimental unit, }(n=6)\end{array}$
\end{tabular}

\section{Discussion}

Growth performance, nutrient intake and apparent digestibility

Weaning stress at the early life of production may arise from the changes in environment, social, nutrient and psychology which potentially compromise productivity, health and welfare [2]. Supplementation of postbiotics in the diet of postweaning lambs enhanced the growth performance by the improvement in final body weight, body weight gain and ADG. Saleem et al. [19] reported that post-weaning lambs supplemented with probiotics had better growth performance in term of final weight gain, total gain, ADG and FCR. Better growth performance in lambs receiving postbiotics was accompanied by the increase in nutrient intake and digestibility of the feed which increase the availability of nutrients to the lambs. Addition of postbiotics in the diet improved nutrient digestibility of DM, CP and NDF. This finding is coherent with Saleem et al. [19] who reported that lambs supplemented with probiotic bacteria improved the digestibility of DM, CP, crude fibre and nitrogen-free extract. Postbiotic effect in term of promoting dry matter intake and improving fibre degradability is similar to the mode of action of probiotic bacteria. This may be explained by the improvement of the concentration of cellulolytic bacteria in the lambs supplemented with probiotics in the diet [20]. The increase in the rumen microbes will increase in the synthesis of microbial protein and provide higher amino acid supply to postruminal which help lambs to gain greater body weight [21].

Table 5 Ruminal microbial population ( $\log _{10}$ microbial $/ \mathrm{mL}$ ) in post-weaning lambs supplemented with and without postbiotics

\begin{tabular}{lllll}
\hline Parameters & Control & Postbiotic & SEM & $P$-value \\
\hline Total bacteria & 10.62 & 10.96 & 0.10 & 0.09 \\
F. succinogenes & $4.57^{\mathrm{a}}$ & $5.81^{\mathrm{b}}$ & 0.32 & 0.04 \\
R. flavefaciens & $11.58^{\mathrm{a}}$ & $13.06^{\mathrm{b}}$ & 0.30 & 0.01 \\
R. albus & 10.78 & 11.08 & 0.62 & 0.83 \\
Protozoa & 6.52 & 5.58 & 0.26 & 0.07 \\
Methanogens & $10.76^{\mathrm{a}}$ & $10.03^{\mathrm{b}}$ & 0.12 & 0.03 \\
\hline
\end{tabular}

a,b Different superscripts in each row are significantly different $(P<0.05)$. Experimental unit, $(n=6)$ 


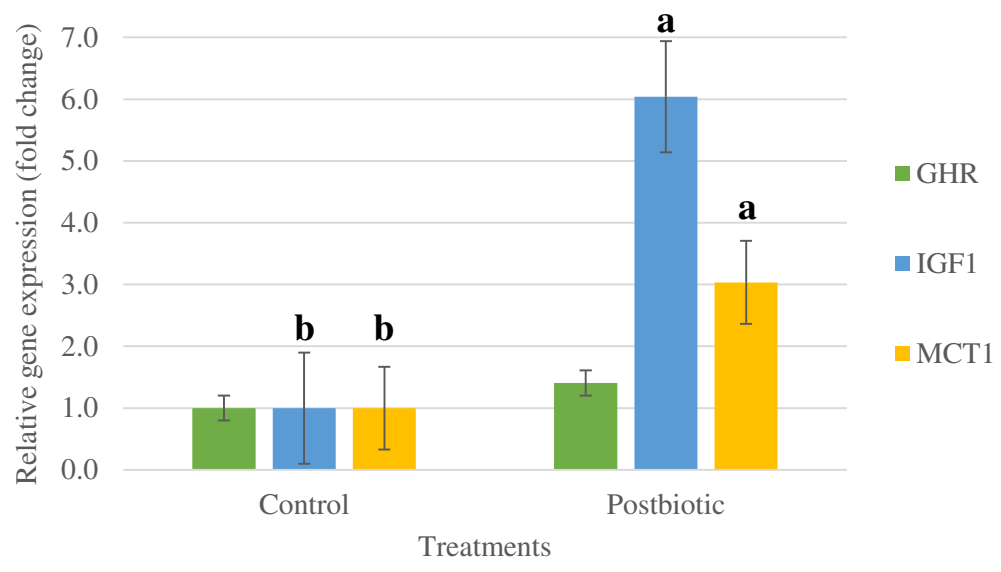

Fig. 1 The GHR, IGF-1 and MCT-1 gene expression in post-weaning lambs fed with and without postbiotics. GHR Growth hormone receptor; IGF1 Insulin-like growth factor 1; MCT-1 Monocarboxylate transporter 1. ${ }^{a}, \mathrm{~b}$ Bar with different letter significantly differ $(P<0.05)$. Experimental unit, $(n=6)$

In the present study, the increase in nutrient digestibility and intake due to postbiotic supplementation could provide greater protein and metabolizable energy to the lambs leading to better growth performance. In addition, the presence of antimicrobial compounds in postbiotics such as bacteriocins and organic acids exhibit inhibitory effect against various pathogens $[16,17]$ in the gastrointestinal tract providing better nutrient digestibility and absorption by the lambs. Galina et al. [22] found that the inclusion of a mixture of probiotic Lactobacillus in growing goats improved fibre and protein digestibility and enhanced microbial synthesis. Thanh et al. [16] reported that postbiotic inclusion in the diet of broilers decreased the proliferation of pathogenic bacteria which may ultimately improve feed utilization and thereby animal performance.

\section{Rumen fermentation characteristics}

The value of rumen $\mathrm{pH}$ recorded in the present study was low considering higher concentrate ratio in the diet. The $\mathrm{pH}$ lower than 5.5 is prone to subacute rumen acidosis but with no clinical signs until the $\mathrm{pH}$ is below 5 which is considered acute or clinical acidosis [23]. Inclusion of postbiotics in the diet of lambs did not change the ruminal $\mathrm{pH}$. It was consistent to the finding by Izuddin et al. [24] who reported postbiotic inclusion had no effect on rumen fluid $\mathrm{pH}$ in vitro. This finding was also observed by Vosooghi-Poostindoz et al. [25] who found no differences in $\mathrm{pH}$ in the lambs receiving probiotics at $16.5 \% \mathrm{CP}$ in the diet. Although the $\mathrm{pH}$ of the postbiotics is low (pH 3.8-4.3), supplementation of $0.9 \%$ of postbiotics in the diet did not alter the rumen $\mathrm{pH}$. No changes in rumen $\mathrm{pH}$ may suggest the adaptation and regulation of rumen environment to the presence of lactic acid from supplementation of postbiotics in the diet.
Postbiotics in the diet of lambs increased ruminal $\mathrm{NH}_{3}-$ $\mathrm{N}$ concentration. Production of ammonia in the rumen is resulted from digestion of dietary protein and non-protein nitrogen by ruminal microorganism. Ammonia is crucial as a source of nitrogen for the growth of ruminal microorganisms and synthesis of microbial proteins. The major factors that influence the ruminal ammonia concentration are the amount of protein in the diet and the degradability of the protein in the rumen. The increase in degradability of protein in the rumen increases the ruminal concentration of ammonia. In the current study, the higher $\mathrm{NH}_{3}-\mathrm{N}$ concentration in the postbiotic diet was in line with the higher crude protein digestibility in lambs.

Supplementation of postbiotics in in vitro rumen fermentation has shown the increase in concentration of total and major individual VFA such as acetic, propionic and butyric [24]. However, postbiotic inclusion in post-weaning lambs did not affect total and individual VFA except for propionic acid. The finding was consistent with Astuti et al. [26] who reported the use of $L$. plantarum as probiotics in in vitro rumen fermentation study showed no effect on total VFA production. The finding was also consistent with Qadis et al. [27] who found no effect of probiotics from L. plantarum, Enterococcus faecium and Clostridium butyricum on total VFA in rumen fluid. The presence of high portion of lactic acid in the postbiotics provides a constant supply of lactic acid that might stimulate the lactic acid utilizing bacteria. Lactic acid utilizing bacteria such as Propionibacterium spp. produce more propionic acid rather than lactic acid [3] that may contribute to the greater molarity of propionic acid in the rumen fluid of lambs supplemented with postbiotics.

\section{Blood metabolites}

Lambs received postbiotics in the diet had higher blood level of total protein, BUN and glucose. The L. plantarum 
generates certain carbohydrates into simpler compounds like glucose, which provides energy [28]. Higher blood glucose level in lambs supplemented with postbiotics might be associated with higher production and absorption of propionic acid as it is the precursor of glucose that enhances glucose production [29]. Likewise, higher population of Propionibacterium present in the rumen particularly in average concentrate diet alter the conditions in the rumen through utilization and conversion of lactic acid into propionic acid resulting in higher creation of hepatic glucose [30].

Blood total protein and BUN concentration can be a valuable indicator of the protein status in animals. Higher blood total protein and BUN concentration may be due to higher microbial digestibility producing high ammonia causing incapacity of ruminal microflora to optimally detain the ammonia [31]. The outcome was contrary to Saleem et al. [19] who found probiotic supplementation in post-weaning lambs has no effect on blood total protein and decreased blood urea. The discrepancy in these findings could be due to different capacity of nutrient digestibility or nitrogen utilization in the rumen which is reflected in the blood. No changes were detected in the serum level of triglycerides and cholesterol in control and postbiotic treatments. It can be related to the fact that no effect of postbiotics on crude fat digestibility and absorption of products of fat digestion by the small intestine. This is consistent with the findings of Vosooghi-Poostindoz et al. [25] who reported no difference in blood concentration of triglyceride and cholesterol in post-weaning lambs supplemented with probiotics at $16.5 \% \mathrm{CP}$ in the diet.

\section{Rumen microbial population}

The population of total bacteria, $R$. albus and total protozoa were not affected in both groups. The inclusion of postbiotics increased the population of cellulolytic bacteria, F. succinogenes and $R$. flavefaciens in the rumen. Izuddin et al. [24] reported the supplementation of postbiotics from $L$. plantarum RG14 in in vitro rumen fermentation increased total bacteria, total protozoa and major cellulolytic bacteria. The mechanisms of probiotic LAB in the rumen in modulating and interacting with rumen microorganisms are still unclear. Weinberg et al. [4] suggested the benefits of probiotic LAB on the improvement of rumen fermentation are due to the interaction of probiotic $\mathrm{LAB}$ and rumen microorganisms and inhibition of detrimental microorganisms by the presence of a variety of antimicrobial compounds such as bacteriocins. Similar to probiotic LAB, the presence of the lactic acid in postbiotics may enhance the adaptation of rumen microorganisms to lactic acid or impede the accumulation of lactic acid by anaerobic degradation of lactic acid to acetic acid as suggested by Ghorbani et al. [32] and Nocek et al. [33] which these conditions would promote the cellulolytic activities and improve degradation of fibres [34]. The cellulolytic bacteria such as $F$. succinogenes and $R$. flavefaciens increased with postbiotic supplementation may explain the improvements in cellulolytic activity leading to better digestion of DM and NDF of feed.

The lower ruminal population of methanogens was discovered following supplementation of postbiotics in lambs. Higher synthesis of propionate in the postbiotic group indicates the reduction of methane formation and increase in retention of energy from the diet [35]. Production of propionate is involving in $\mathrm{H}_{2}$-utilisation pathway and as $\mathrm{H}_{2}$ is the main precursor of methane formation, decreased in the availability of $\mathrm{H}_{2}$ is associated with a decrease in methane production $[35,36]$. This condition may reflect the reduction of ruminal methanogens population in the postbiotic group as the depletion of $\mathrm{H}_{2}$ as the source of methane production by methanogens.

\section{Gene expression}

In the current study, post-weaning lambs received postbiotics had higher regulation of hepatic IGF-1 mRNA by 5 folds compared to control. The IGF-1 is the mediator of pituitary growth hormone which is synthesized and secreted in the liver to stimulate cell growth. The increase in expression of IGF-1 reflected in the growth performance of lambs supplemented with postbiotics. Mears [37] reported that plasma IGF-1 concentration in lambs at an early age has a positive correlation with the growth rates and it could be a useful indicator of growth potential and aid in the selection of fast-growing animals. Similar finding was reported as postbiotic supplementation in the diet of broilers increased the growth performance of birds and enhanced the fold expression of IGF-1 and GHR mRNA [12].

Postbiotic inclusion in the diet of post-weaning lambs upregulated the MCT-1 mRNA expression in the rumen tissue. Higher expression of MCT-1 gene can be associated with higher uptake of VFA and their metabolites through rumen epithelium into the blood to be metabolized to generate energy. Kuzinski and Röntgen [38] reported the elevated level of butyric acid in the rumen of lambs shifted from hay diet to hay and concentrate diet responsible for the upregulation of MCT-1 mRNA. However, in the current study, no differences were observed in butyric acid concentration in rumen fluid between control and postbiotic groups. Besides nutritional induction, MCT-1 gene can be upregulated by the synthetic peroxisome proliferator-activated receptor $\alpha$ $($ PPAR- $\alpha)$ agonists which is a transcription factor that mediates the adaptive response to fasting [39]. In response to feeding and starvation, PPAR- $\alpha$ acts as nutritional sensor which permits adaptation of the rates of fatty acid catabolism, lipogenesis and ketone body synthesis [40, 41]. Dijkstra et al. [42] reported that the rate of absorption of VFA through rumen epithelium linearly increased with the decreasing ruminal $\mathrm{pH}$. The decline in the $\mathrm{pH}$ will provide a higher proportion of VFA in the undissociated form which is more permeable across the lipid bilayer of the cell wall [43]. 
In the present study, slightly lower $\mathrm{pH}$ of rumen fluid in the postbiotic group can contribute to a greater uptake of the VFA.

\section{Conclusions}

The findings from the current study showed that the inclusion of $0.9 \%$ postbiotics from L. plantarum RG14 improved growth performance, nutrient intake and nutrient digestibility in the diet of post-weaning lambs. The improvement of growth and feed utilization in lambs fed with postbiotics were reflected by the rumen fermentation characteristics, ruminal cellulolytic bacteria population and blood metabolites. The higher expression of hepatic IGF-1 and ruminal MCT-1 mRNA resulted in higher production of IGF-1 in the liver and greater uptake of VFA through the ruminal epithelium, respectively. Postbiotics are the potential feed additive to be used to promote rumen fermentation and growth of post-weaning ruminant animals. We extrapolate the effects of postbiotics would be similar in different sexes of lambs, however the effects of postbiotics on growth and reproductive performance in female lambs are worth to be explored in the near future.

\section{Methods}

\section{Microorganisms and maintenance}

The L. plantarum RG14 was obtained from the Laboratory of Industrial Biotechnology, Department of Bioprocess Technology, Faculty of Biotechnology and Biomolecular Sciences, Universiti Putra Malaysia. The bacterial cultures was maintained and revived as described by Foo et al. [44] and Moghadam et al. [45]. The bacterial cultures were maintained at $-20{ }^{\circ} \mathrm{C}$ in de Man, Rogosa and Sharpe (MRS) medium (Merck, Germany) supplemented with 20\% (v/v) glycerol.

\section{Postbiotic production from $L$. plantarum RG14}

The active $L$. plantarum RG14 was washed once with sterile $0.85 \%(\mathrm{w} / \mathrm{v}) \mathrm{NaCl}$ (Merck, Germany) solution and adjusted to $10^{9} \mathrm{CFU} / \mathrm{mL}$ to be used as inoculum. The working cultures of L. plantarum RG14 was prepared by inoculating $10 \%(\mathrm{v} / \mathrm{w})$ of $10^{9} \mathrm{CFU} / \mathrm{mL}$ active bacterial cell into MRS media and incubated at $30^{\circ} \mathrm{C}$ for $10 \mathrm{~h}$, followed by centrifugation (Benchtop Microfuge 20R, Beckman Coulter, Germany) at $10,000 \times \mathrm{g}, 4^{\circ} \mathrm{C}$ for $15 \mathrm{~min}$. The cell free supernatant (CFS) was then collected by filtration through a cellulose acetate membrane (Sartorius Minisart, $0.22 \mu \mathrm{m}$, Germany) as described by Loh et al. [46]. The CFS was stored at $-20^{\circ} \mathrm{C}$ until feeding trial was conducted.

\section{Animals and management}

The study was conducted in the Department of Animal Science Research Farm, Universiti Putra Malaysia. A total of twelve healthy newly-weaned, gonadally intact male Dorper lambs at 112 days of age with an average body weight of $17.3 \pm 0.58 \mathrm{~kg}$ (at the beginning of adaptation period) were randomly allocated to two treatment groups. The control group received no postbiotics and the other group received $0.9 \%(\mathrm{v} / \mathrm{w})$ postbiotics in the diet. The level of inclusion was based on the in vitro study reported by Izuddin et al. [24]. The lambs were individually housed in slatted floor pen $(1 \mathrm{~m} \times 1.5 \mathrm{~m})$ and offered the isocaloric and isonitrogenous diet for 60 days including 14 days of adaptation period. The diets were formulated according to nutritional requirements of sheep by NRC [47] using FeedLIVE software (Thailand). The ingredients and chemical composition of the diets are presented in Table 6 . The amount of grass and concentrate offered was adjusted weekly based on the $4 \%$ of body weight of that particular week. Grass was given in the morning at 08:00 and concentrate was added in the evening at 16:00 daily. The daily amount of individual lamb intake of grass was considered during experimental period to ensure the concentrate given meet the grass to concentrate ratio. Fresh drinking water was continuously provided in each pen.

\section{Data, sample collection and analysis}

Body weight of the lambs was recorded before the morning feeding at the beginning of the feeding trial and on weekly basis throughout the feeding trial. Feed intake was determined daily by measuring the difference in the amount of feed offered and refusal. The moisture content of the feed offered and refused was considered on

Table 6 Feed composition and nutrient content of the feed

\begin{tabular}{|c|c|c|}
\hline & Control & Postbiotic \\
\hline \multicolumn{3}{|l|}{ Feed composition (\%) } \\
\hline Grass & 30.00 & 30.00 \\
\hline Corn & 40.00 & 40.00 \\
\hline Soybean & 23.80 & 23.80 \\
\hline Wheat pollard & 3.40 & 3.40 \\
\hline Crude palm oil & 0.90 & 0.90 \\
\hline Calcium carbonate & 1.70 & 1.70 \\
\hline Salt & 0.40 & 0.40 \\
\hline Mineral premix ${ }^{a}$ & 0.90 & 0.90 \\
\hline Vitamin premix ${ }^{\mathrm{b}}$ & 0.90 & 0.90 \\
\hline Postbiotic RG14 & - & 0.90 \\
\hline \multicolumn{3}{|c|}{ Chemical nutrient composition (g/kg DM) } \\
\hline Crude protein & 169.00 & 169.00 \\
\hline Crude fat & 27.00 & 26.70 \\
\hline NDF & 596.00 & 596.00 \\
\hline ADF & 169.00 & 166.00 \\
\hline
\end{tabular}

${ }^{a}$ Mineral mix contains Co $0.6 \mathrm{mg}$, Cu $20 \mathrm{mg}$, Fe $100 \mathrm{mg}, \mathrm{I} 2 \mathrm{mg}, \mathrm{Mn} 110 \mathrm{mg}$, Se $0.2 \mathrm{mg}, \mathrm{Zn} 100 \mathrm{mg}$

${ }^{b}$ Vitamin premix contains vitamin A $0.45 \mathrm{mlU} / \mathrm{kg}$, vitamin B1 $0.09 \mathrm{~g} / \mathrm{kg}$, vitamin B2 $0.27 \mathrm{~g} / \mathrm{kg}$, vitamin B6 $0.18 \mathrm{~g} / \mathrm{kg}$, vitamin B12 $0.09 \mathrm{mg} / \mathrm{kg}$, vitamin D3 0.09 $\mathrm{mlU} / \mathrm{kg}$, vitamin E $0.67 \mathrm{~g} / \mathrm{kg}$, vitamin $\mathrm{K} 30.18 \mathrm{~g} / \mathrm{kg}$, biotin $2.12 \mathrm{mg} / \mathrm{kg}$ of feed NDF Neutral detergent fibre, ADF Acid detergent fibre

The diets were formulated using feed live international software (Thailand) 
daily basis to correct dry matter intake of the feed. During the experimental period, the ratio of the grass to concentrate was maintained at the 30:70. Feed conversion ratio (FCR) was calculated for each individual lamb from total feed intake and total weight gain during the experimental period. In determination of nutrient digestibility, daily feed and faecal collection was done for seven consecutive days at the final week of the feeding trial in the morning. Daily total faecal voided was weighed and $10 \%(\mathrm{w} / \mathrm{w})$ of the total faecal was sampled and kept frozen at $-20^{\circ} \mathrm{C}$. At the end of the collection period, faecal samples of the individual lamb for 7 days were composited and subsampled for further analysis. Blood samples were collected by jugular venepuncture on day 58 of the feeding trial period before morning feeding into the BD Vacutainer serum tube.

At day 60 of the feeding trial, all lambs were transferred to the research abattoir in the Department of Animal Science, Universiti Putra Malaysia to fast overnight in the lairage with access to fresh drinking water. The following day, the lambs were sacrificed without stunning according to the Halal slaughtering procedure (MS1500: 2009) by severing the carotid artery and jugular vein as outlined by Malaysian Standard [48]. After slaughtering, lambs were eviscerated for the collection of rumen fluid, rumen and liver tissues. Rumen fluid was collected for the analysis of $\mathrm{pH}$, ammonia- $\mathrm{N}\left(\mathrm{NH}_{3}-\right.$ N) concentration, VFA and microbial population. Ruminal $\mathrm{pH}$ was measured shortly after rumen fluid collection from rumen using a $\mathrm{pH}$ meter (Mettler-Toledo Ltd., England, UK). Approximately $2 \mathrm{~cm}^{2}$ of rumen tissues from the caudal dorsal of rumen and small portion of liver from left lobe of liver were collected and immediately frozen in liquid nitrogen and kept in $-80^{\circ} \mathrm{C}$ freezer upon extraction of RNA.

\section{Proximate analysis and apparent digestibility}

The DM content was determined by drying at $60^{\circ} \mathrm{C}$ for $24 \mathrm{~h}$. Analytical DM of the oven-dried samples was determined by drying at $105^{\circ} \mathrm{C}$ for $24 \mathrm{~h}$. Ash content was determined by combustion of samples in $550^{\circ} \mathrm{C}$ muffle furnace for $5 \mathrm{~h}$. Nitrogen content was determined by the Kjeldahl method using Foss Digestor ${ }^{\text {rax }}$ System for sample digestion and Foss Kjeltec 2300 for distillation and titration [49]. Crude fat was determined by ether extract method using the Foss Tecator Soxtec 2050 Avanti (FOSS, Denmark). Contents of NDF and ADF were determined by neutral detergent and acid detergent solutions respectively following the methods detailed by Van Soest et al. [50]. Feed and faecal samples were analysed for DM, OM, CP, EE and NDF for the determination of apparent digestibility.

\section{Blood metabolites}

The serum was separated and collected by centrifugation at $3000 \mathrm{rpm}$ for $5 \mathrm{~min}$ for the determination of blood metabolites. The analysis of glucose, total protein, urea nitrogen, triglyceride and cholesterol levels in the serum were determined by Hitachi 902 Automatic Analyser (Roche Diagnostics, Germany) using appropriate kits.

\section{Ruminal $\mathrm{NH}_{3}-\mathrm{N}$ and VFA}

Thawed rumen fluid samples were centrifuged for $6000 \times \mathrm{g}$ for $10 \mathrm{~min}$ at room temperature. Supernatant collected were analysed for $\mathrm{NH}_{3}-\mathrm{N}$ based on the protocol described by Parsons et al. [51]. The absorbance of the colour intensity was measured at $640 \mathrm{~nm}$ by using Spectrophotometer (GENESYS ${ }^{\mathrm{ma}} 20$ Thermo Scientific ${ }^{\mathrm{Tx}}$, USA). The concentration of $\mathrm{NH}_{3}-\mathrm{N}$ was determined by constructing a standard curve of known concentration and substituting the absorbance of the sample in the standard curve equation. For the analysis of VFA, rumen fluid was acidified with $25 \%$ metaphosphoric acid (w/v) in the ratio of $4: 1(\mathrm{v} / \mathrm{v})$ respectively and centrifuged at $3000 \times \mathrm{g}$ for $10 \mathrm{~min}$. The supernatant was collected, filtered and used for VFA determination. The 4-methyl-nvaleric acid (Sigma, St. Louis, MO) was used as an internal standard. Then, $0.5 \mathrm{~mL}$ of clear supernatant was collected and mixed with equal volume of 4-methyl-valeric acid (Sigma-Aldrich, St. Louis, MO) as internal standard. The VFA of the rumen fluid were analysed using a $6890 \mathrm{~N}$ Network GC System gas chromatograph (Agilent Technologies) according to Filípek and Dvořák [52]. Separation of VFA profile was determined using Quadrex 007 Series (Quadrex Corp., New Haven, CT 06525, USA) bonded phase fused silica capillary column $(15 \mathrm{~m}, 0.250 \mathrm{~mm}$ ID, $0.25 \mu \mathrm{m}$ film thickness) with a $6890 \mathrm{~N}$ Network GC System gas chromatograph (Agilent Technologies) equipped with a flame ionisation detector. Nitrogen gas was supplied as carrier gas at the rate of $60 \mathrm{~mL} / \mathrm{min}$. The temperature of the column was set at $200^{\circ} \mathrm{C}$ and injector and detector both at $230^{\circ} \mathrm{C}$. Commercial standards (Sigma-Aldrich, St. Louis, $\mathrm{MO}$ ) of $20 \mathrm{mM}$ acetic, and $10 \mathrm{mM}$ each of propionic, butyric and 4-methyl-valeric acids were used as external standards for peak identification. Molar concentration of VFA were identified based on single point of internal and external standards.

\section{Rumen microbial population}

The isolation of microbial DNA in rumen fluid using QIAamp ${ }^{\circ}$ Fast DNA Stool Mini Kit (Qiagen, Hilden, Germany), following the manufacturer's protocol. The DNA concentration was measured using Nanodrop 2000 spectrophotometer (Thermo Scientific, Wilmington, DE). Only high DNA concentration of higher than 30 $\mathrm{ng} / \mu \mathrm{L}$ and high purity was chosen for further manipulation. Absolute quantification of microbes in the rumen fluid was performed based on the standard curve of amplification of target microbes. The populations of total bacteria, Ruminococcus albus, Ruminococcus flavefaciens, Fibrobacter succinogenes, methanogens and 
Table 7 Sequence of polymerase chain reaction primers used to target microbes

\begin{tabular}{lll}
\hline Target microbes & Primer & References \\
\hline Total bacteria & F - CGGCAACGAGCGCAACCC & {$[53]$} \\
& R - CCATTGTAGCACGTGTGTAGCC & \\
F. succinogenes & F - GTTCGGAATACTGGGCGTAAA & {$[54]$} \\
& R - CGCCTGCCCTGAACTATC & \\
R. albus & F - CCCTAAAAGCAGTCTTAGTTCG & {$[55]$} \\
& R - CCTCCTTGCGGTAGAACA & \\
R. flavefaciens & F - TCTGGAAACGGATGGTA & {$[55]$} \\
Methanogens & R - CCTTAAGACAGGAGTTACAA & \\
& F - TTCGGTGGATCDCARAGRGC & {$[56]$} \\
Protozoa & F - GBARGTCGWAWCCGTAGAATC & \\
& R - CTTGCCCTCYAATCGTWCT & {$[57]$} \\
\hline
\end{tabular}

$F$ Forward, $R$ Reverse

protozoa were analysed by using qPCR. The targeted microbes, the sequences of the forward and reverse primers and the annealing temperature are shown in Table 7. Real-time qPCR was performed with the Bio-Rad CFX96 Real-time PCR system (Bio-Rad Laboratories, CA, USA). The qPCR cycling condition consisting of initial heat activation at $95^{\circ} \mathrm{C}$ for $10 \mathrm{~min}$, following by 40 cycles of denaturation at $95^{\circ} \mathrm{C}$ for $15 \mathrm{~s}$, annealing at $55^{\circ} \mathrm{C}$ for total bacteria, F. succinogenes, $R$. albus and protozoa, $58^{\circ} \mathrm{C}$ for methanogens and $60^{\circ} \mathrm{C}$ for $R$. flavefaciens for $30 \mathrm{~s}$ and finally $30 \mathrm{~s}$ of extension at $72{ }^{\circ} \mathrm{C}$. The analysis of melting curve was performed at the end of the amplification cycle to confirm the specificity of amplification.

\section{RNA extraction and RT-PCR of GHR, IGF-1 and MCT-1 genes}

The tissues were pulverized by mortar and pestle with presence of liquid nitrogen. Total RNA was isolated from liver and rumen tissues samples using RNeasy ${ }^{\circ}$ Mini Kit (Qiagen, Hilden, Germany), following the manufacturer's protocol. The concentration and purity (260/ $280 \mathrm{~nm}$ ratio of absorbance readings) of RNA were quantified by Nanodrop 2000 spectrophotometer (Thermo Scientific, Wilmington, DE). Approximately
$100 \mathrm{ng} / \mu \mathrm{L}$ purified RNA was converted into complementary DNA (cDNA) using Quantitect ${ }^{\bullet}$ reverse transcription kit (Qiagen, Hilden, Germany) following the manufacturer's procedure. The genomic DNA removal was performed before the reverse transcription of RNA to cDNA. Real-time qPCR was performed with the BioRad CFX96 Real-time PCR system (Bio-Rad Laboratories, CA, USA). The targeted genes, the sequences of primers, product size are described in Table 8 . The qPCR cycling condition consisting of initial heat activation at $95^{\circ} \mathrm{C}$ for $10 \mathrm{~min}$, following by 40 cycles of denaturation at $95^{\circ} \mathrm{C}$ for $15 \mathrm{~s}$, annealing at $57^{\circ} \mathrm{C}$ for GADPH and GHR genes, $60^{\circ} \mathrm{C}$ for MCT-1 gene for $30 \mathrm{~s}$ and finally $30 \mathrm{~s}$ of extension at $72{ }^{\circ} \mathrm{C}$. The analysis of melting curve was performed at the end of the amplification cycle to confirm the specificity of amplification. The annealing temperature of target and reference genes were determined by the gradient protocol of Bio-Rad CFX96 Real-time PCR System (Bio-Rad Laboratories, CA, USA). The relative expression of the gene was measured according to the Livak's method of $2^{-\Delta \Delta \mathrm{Ct}}(\Delta \Delta \mathrm{Ct}=$ $\Delta \mathrm{Ct}$ treated sample - $\Delta \mathrm{Ct}$ control sample) as described by Livak and Schmittgen [58]. For the internal standard (housekeeping gene), GADPH gene was used as to standardize the expression. The efficiency of amplification of target and housekeeping genes was determined by a 5 -fold serial dilution of cDNA as a standard curve. All the standard curves showed good PCR amplification efficiencies between 90 to $120 \%$.

\section{Statistical analysis}

The experiment was subjected to a completely randomized design. For each parameter, the individual lamb was considered as one experimental unit. The differences between treatments were analysed using independent $\mathrm{t}$ test. The initial body weight of lambs was used as covariate and it was analysed using analysis of covariance. The statistical software of SAS (Statistical Analysis System) software version 9.2 (SAS Institute, USA) was used to analyse the data. Differences between treatment means were considered significant at $P<0.05$.

Table 8 Primer information of target and reference genes

\begin{tabular}{|c|c|c|c|}
\hline Target gene & Primer Sequence $\left(5^{\prime}-3^{\prime}\right)$ & Product size (bp) & NCBI accession number \\
\hline GHR & $\begin{array}{l}\text { F - GCCAAAACAATAAGACTGGGAACC } \\
\text { R - GGCTGTAGTGGTAAGGCTTTCTGTG }\end{array}$ & 218 & XM_012096676.1 \\
\hline IGF-1 & $\begin{array}{l}\text { F - ATTACAGCTGCCTGCCCCTT } \\
\text { R - CACATCTGCTTACACCTTACCCG }\end{array}$ & 265 & NM_001009774.3 \\
\hline MCT-1 & $\begin{array}{l}\text { F - TGGCATCTTATCAGGCAGTGG } \\
\text { R - CCAGCCACACAGCAGTTTAATAG }\end{array}$ & 300 & XM_004002335.3 \\
\hline GADPH & $\begin{array}{l}\text { F - ACCACTTTGGCATCGTGGAG } \\
\text { R - GGGCCATCCACAGTCTTCTG }\end{array}$ & 76 & NM_001190390.1 \\
\hline
\end{tabular}

F Forward, R Reverse, GHR Growth hormone receptor, IGF-1 Insulin-like growth factor 1, MCT-1 Monocarboxylate transporter 1, GADPH Glyceraldehyde 3-phosphate dehydrogenase 


\section{Abbreviations}

ADG: Average daily gain; BUN: Blood urea nitrogen; CP: Crude protein; DM: Dry matter; EE: Ether extract; GHR: Growth hormone receptor; IGF1: Insulin-like growth factor 1; LAB: Lactic acid bacteria; MCT-

1: Monocarboxylate transporter 1; NDF: Neutral detergent fibre; $\mathrm{NH}_{3}{ }^{-}$ $\mathrm{N}$ : Ammonia nitrogen; OM: Organic matter; VFA: Volatile fatty acid

\section{Acknowledgments}

'Not applicable'.

\section{Authors' contributions}

IWI, LTC, SAA, FHL participated in the study design and performed statistical analysis. IWI involved in feeding trial. IWI, HAM and SN conducted sample collection and laboratory analysis. IWI, LTC, SAA, FHL, HAM and SN contributed to the preparation of manuscript. All the authors read and approved the final manuscript.

\section{Authors' information}

'Not applicable'.

\section{Funding}

This study was financed by the Putra Graduate Initiative (IPS) Research Grant, Universiti Putra Malaysia. The funding body approved the proposed study design, data collection and analysis but not involved in the writing of manuscript.

\section{Availability of data and materials}

The datasets used and/or analysed during the current study are available from the corresponding author on reasonable request.

\section{Ethics approval and consent to participate}

The experimental protocol was followed according to the guidelines approved by the Research Committee of the Universiti Putra Malaysia (No. 9525500: Effects of inclusion of postbiotic from Lactobacillus plantarum in post-weaning lambs). The lambs used for the trial were provided by the research farm of Universiti Putra Malaysia.

\section{Consent for publication}

'Not applicable'.

\section{Competing interests}

The authors declare that they have no competing interests.

\section{Author details}

${ }^{1}$ Department of Animal Science, Faculty of Agriculture, Universiti Putra Malaysia, 43400 Serdang, Selangor, Malaysia. ${ }^{2}$ Institute of Tropical Agriculture and Food Security, Universiti Putra Malaysia, 43400 Serdang, Selangor, Malaysia. ${ }^{3}$ Department of Bioprocess Technology, Faculty of Biotechnology and Biomolecular Sciences, Universiti Putra Malaysia, 43400 Serdang, Selangor, Malaysia. ${ }^{4}$ Institute of Bioscience, Universiti Putra Malaysia, 43400 Serdang, Selangor, Malaysia. ${ }^{5}$ Department of Animal Resources, Faculty of Agriculture, University of Baghdad, Baghdad, Iraq

\section{Received: 18 October 2018 Accepted: 26 August 2019}

Published online: 02 September 2019

\section{References}

1. Sowinska J, Brzostowski H, Tanski Z, Czaja K. The weaning stress response in lambs of different age. Czech J Anim Sci. 2001;46(11):465-8.

2. Karakus F. Weaning stress in lambs. J Int Sci Publ Agric Food. 2014;2:165-70.

3. Seo JK, Kim SW, Kim MH, Upadhaya SD, Kam DK, Ha JK. Direct-fed microbials for ruminant animals. Asian-australas J Anim Sci. 2010;23(12):1657-67.

4. Weinberg Z, Muck R, Weimer P. The survival of silage inoculant lactic acid bacteria in rumen fluid. J Appl Microbiol. 2003;94(6):1066-71.

5. Dawson K Newman K, Boling J. Effects of microbial supplements containing yeast and lactobacilli on roughagefed ruminal microbial activities. J Animal Sci. 1990,68(10):3392-8.

6. Oyetayo V, Oyetayo F. Potential of probiotics as biotherapeutic agents targeting the innate immune system. Afr J Biotechnol. 2005:4(2):123-7.

7. Antunović $Z$, Šperanda M, Amidžić D, Šerić V, Stainer Z, Domačinović M, et al. Probiotic application in lambs nutrition. Primjena Probiotika u Hranidbi Janjadi. 2006;48(4):175-80.
8. Whitley NC, Cazac D, Rude B, Jackson-O'Brien D, Parveen S. Use of a commercial probiotic supplement in meat goats. J Animal Sci. 2009;87(2):723-8.

9. Marteau P, Shanahan F. Basic aspects and pharmacology of probiotics: an overview of pharmacokinetics, mechanisms of action and side-effects. Best Pract Res Clin Gastroenterol. 2003;17(5):725-40.

10. Shazali N, Foo HL, Loh TC, Choe DW, Rahim RA. Prevalence of antibiotic resistance in lactic acid bacteria isolated from the faeces of broiler chicken in Malaysia. Gut Pathog. 2014;6(1):1.

11. Loh TC, Thanh NT, Foo HL, Hair-Bejo M, Azhar BK. Feeding of different levels of metabolite combinations produced by Lactobacillus plantarum on growth performance, fecal microflora, volatile fatty acids and villi height in broilers. Anim Sci J. 2010;81(2):205-14.

12. Kareem KY, Loh TC, Foo HL, Akit H, Samsudin AA. Effects of dietary postbiotic and inulin on growth performance, IGF1 and GHR mRNA expression, faecal microbiota and volatile fatty acids in broilers. BMC Vet Res. 2016;12(1):163.

13. Loh TC, Choe DW, Foo HL, Sazili AQ, Bejo MH. Effects of feeding different postbiotic metabolite combinations produced by Lactobacillus plantarum strains on egg quality and production performance, faecal parameters and plasma cholesterol in laying hens. BMC Vet Res. 2014;10(1):149.

14. Thu TV, Loh TC, Foo HL, Yaakub H, Bejo MH. Effects of liquid metabolite combinations produced by Lactobacillus plantarum on growth performance, faeces characteristics, intestinal morphology and diarrhoea incidence in postweaning piglets. Trop Anim Health Prod. 2011;43(1):69-75.

15. Loh TC, Thu TV, Foo HL, Bejo MH. Effects of different levels of metabolite combination produced by Lactobacillus plantarum on growth performance, diarrhoea, gut environment and digestibility of postweaning piglets. J Appl Anim Res. 2013:41(2):200-7.

16. Thanh NT, Chwen LT, Foo HL, Hair-Bejo M, Kasim AB. Inhibitory activity of metabolites produced by strains of Lactobacillus plantarum isolated from Malaysian fermented food. Int J Probiotics Prebiotics. 2010;5(1):37.

17. Choe DW, Foo HL, Loh TC, Bejo MH, Sazili AQ. Inhibitory property of metabolite combinations produced from Lactobacillus plantarum strains. Pertanika J Trop Agric Sci. 2013;36(1):79-88.

18. Thu TV, Foo HL, Loh TC, Bejo MH. Inhibitory activity and organic acid concentrations of metabolite combinations produced by various strains of Lactobacillus plantarum. Afr J Biotechnol. 2011;10(8):1359-63.

19. Saleem A, Zanouny A, Singer A. Growth performance, nutrients digestibility, and blood metabolites of lambs fed diets supplemented with probiotics during pre-and post-weaning period. Asian-australas J Anim Sci. 2017;30(4):523.

20. Wallace RJ, Newbold CJ. Rumen fermentation and its manipulation: the development of yeast cultures as feed additives. In Lyons TP, editor, Biotechnology in the food industry. Nicholasville: Alltech Technical Publications; 1993. p. 173-92

21. Erasmus L, Botha P, Kistner A. Effect of yeast culture supplement on production, rumen fermentation, and duodenal nitrogen flow in dairy cows. J Dairy Sci. 1992:75(11):3056-65.

22. Galina M, Ortiz-Rubio M, Delgado-Pertinez M, Pineda L. Goat kid's growth improvement with a lactic probiotic fed on a standard base diet. Options Mesditerranéennes. 2009;85:315-23.

23. Jasmin $\mathrm{BH}$, Boston RC, Modesto RB, Schaer TP. Perioperative ruminal pH changes in domestic sheep (Ovis aries) housed in a biomedical research setting. J Am Assoc Lab Anim Sci. 2011;50(1):27-32.

24. Izuddin WI, Loh TC, Samsudin AA, Foo HL. In vitro study of postbiotics from Lactobacillus plantarum RG14 on rumen fermentation and microbial population. R Bras Zootec. 2018;47:1-7.

25. Vosooghi-Poostindoz V, Foroughi A, Delkhoroshan A, Ghaffari M, Vakili R, Soleimani A. Effects of different levels of protein with or without probiotics on growth performance and blood metabolite responses during pre-and post-weaning phases in male Kurdi lambs. Small Rumin Res. 2014;117(1):1-9.

26. Astuti WD, Wiryawan KG, Wina E, Widyastuti Y, Suharti S, Ridwan R. Effects of selected Lactobacillus plantarum as probiotic on in vitro ruminal fermentation and microbial population. Pak J Nutr. 2018;17(3):131-9.

27. Qadis AQ, Goya S, Ikuta K, Yatsu M, Kimura A, Nakanishi S, et al. Effects of a bacteria-based probiotic on ruminal $\mathrm{pH}$, volatile fatty acids and bacterial flora of Holstein calves. J Vet Med Sci. 2014;76(6):877-85.

28. Khalid M, Shahzad M, Sarwar M, Rehman A, Sharif M, Mukhtar N. Probiotics and lamb performance: a review. Afr J Agric Res. 2011;6(23):5198-203.

29. Huntington GB, Eisemann JH. Regulation of nutrient supply by gut and liver tissues. J Animal Sci. 1988;66(suppl_3):35-48. 
30. Stein D, Allen D, Perry E, Bruner J, Gates K, Rehberger T, et al. Effects of feeding propionibacteria to dairy cows on milk yield, milk components, and reproduction. J Dairy Sci. 2006;89(1):111-25.

31. Butler WR. Effect of protein nutrition on ovarian and uterine physiology in dairy cattle. J Dairy Sci. 1998;81(9):2533-9.

32. Ghorbani G, Morgavi D, Beauchemin K, Leedle J. Effects of bacterial directfed microbials on ruminal fermentation, blood variables, and the microbial populations of feedlot cattle 1 2. J Animal Sci. 2002;80(7):1977-85.

33. Nocek J, Kautz W, Leedle J, Allman J. Ruminal supplementation of direct-fed microbials on diurnal $\mathrm{pH}$ variation and in situ digestion in dairy cattle. J Dairy Sci. 2002;85(2):429-33.

34. Jiao P, Liu F, Beauchemin K, Yang W. Impact of strain and dose of lactic acid bacteria on in vitro ruminal fermentation with varying media $\mathrm{pH}$ levels and feed substrates. Anim Feed Sci Technol. 2017;224:1-13.

35. Jeyanathan J, Martin C, Morgavi D. The use of direct-fed microbials for mitigation of ruminant methane emissions: a review. Anim. 2014;8(2):250-61.

36. Baldwin R, Wood W, Emery R. Conversion of glucose-C14 to propionate by the rumen microbiota. J Bacteriol. 1963;85(6):1346-9.

37. Mears $\mathrm{G}$. The relationship of plasma somatomedin (IGF-1) to lamb growth rate. Can J Anim Sci. 1995;75(3):327-31.

38. Kuzinski J, Röntgen $M$. The mRNA and protein expression of ruminal MCT1 is increased by feeding a mixed hay/concentrate diet compared with hay ad libitum diet. Arch Tierzucht. 2011;54(3):280-6.

39. König B, Fischer S, Schlotte S, Wen G, Eder K, Stangl Gl. Monocarboxylate transporter 1 and CD147 are up-regulated by natural and synthetic peroxisome proliferator-activated receptor a agonists in livers of rodents and pigs. Mol Nutr Food Res. 2010;54(9):1248-56.

40. Hashimoto T, Cook WS, Qi C, Yeldandi AV, Reddy JK, Rao MS. Defect in peroxisome proliferator-activated receptor a-inducible fatty acid oxidation determines the severity of hepatic steatosis in response to fasting. J Biol Chem. 2000;275(37):28918-28.

41. Pawlak M, Lefebvre P, Staels B. Molecular mechanism of PPARa action and its impact on lipid metabolism, inflammation and fibrosis in non-alcoholic fatty liver disease. J Hepatol. 2015;62(3):720-33.

42. Dijkstra J, Boer H, Van Bruchem J, Bruining M, Tamminga S. Absorption of volatile fatty acids from the rumen of lactating dairy cows as influenced by volatile fatty acid concentration, $\mathrm{pH}$ and rumen liquid volume. $\mathrm{Br} J$ Nutr. 1993;69(2):385-96.

43. Gäbel G, Aschenbach J, Müller F. Transfer of energy substrates across the ruminal epithelium: implications and limitations. Anim Health Res Rev. 2002;3(1):15-30

44. Foo H, Loh T, Lai P, Lim Y, Kufli C, Rusul G. Effects of adding Lactobacillus plantarum I-UL4 metabolites in drinking water of rats. Pakistan J Nutr. 2003;2(5):283-8.

45. Moghadam MS, Foo HL, Leow TC, Rahim RA, Loh TC. Novel bacteriocinogenic Lactobacillus plantarum strains and their differentiation by sequence analysis of 16 S rDNA, 16 S-23 S and 23 S-5 S intergenic spacer regions and randomly amplified polymorphic DNA analysis. Food Technol Biotechnol. 2010;48(4):476-83.

46. Loh TC, Chong SW, Foo HL, Law FL. Effects on growth performance, faecal microflora and plasma cholesterol after supplementation of spray-dried metabolite to postweaning rats. Czech J Animal Sci. 2009;54(1):10-6.

47. NRC. Nutrient requirements of small ruminants. Washington, DC: National Academy Press; 2007.

48. Malaysia S. Halal food-production, preparation, handling and storage-general guidelines (second revision). Selangor: Department of Standards; 2009.

49. AOAC. Official methods of analysis of AOAC International. Arlington: AOAC Intl pv (loose-leaf); 1995.

50. Van Soest P, Robertson J, Lewis B. Symposium: carbohydrate methodology, metabolism, and nutritional implications in dairy cattle. J Dairy Sci. 1991;74(10):3583-97.

51. Parsons TR, Maita Y, Lalli CM. A manual of chemical and biological methods for seawater analysis: Elsevier; 1984.

52. Filípek J, Dvořák R. Determination of the volatile fatty acid content in the rumen liquid: comparison of gas chromatography and capillary isotachophoresis. Acta Vet Brno. 2009;78(4):627-33.

53. Samsudin AA, Wright A-D, Al JR. The effect of fibre source on the numbers of some fibre-degrading bacteria of Arabian camel's (Camelus dromedarius) foregut origin. Trop Anim Health Prod. 2014;46(7):1161-6.

54. Lane D. 16S/23S rRNA sequencing. Nucleic Acid Techniques in Bacterial Systematics; 1991.
55. Koike S, Kobayashi Y. Development and use of competitive PCR assays for the rumen cellulolytic bacteria: Fibrobacter succinogenes, Ruminococcus albus and Ruminococcus flavefaciens. FEMS Microbiol Lett. 2001;204(2):361-6.

56. Denman SE, MCSweeney CS. Development of a real-time PCR assay for monitoring anaerobic fungal and cellulolytic bacterial populations within the rumen. FEMS Microbiol Ecol. 2006;58(3):572-82.

57. Sylvester JT, Karnati SK, Yu Z, Morrison M, Firkins JL. Development of an assay to quantify rumen ciliate protozoal biomass in cows using real-time PCR. J Nutr. 2004;134(12):3378-84.

58. Livak KJ, Schmittgen TD. Analysis of relative gene expression data using realtime quantitative $P C R$ and the 2- $\Delta \Delta C T$ method. Methods. 2001:25(4):402-8.

\section{Publisher's Note}

Springer Nature remains neutral with regard to jurisdictional claims in published maps and institutional affiliations.
Ready to submit your research? Choose BMC and benefit from:

- fast, convenient online submission

- thorough peer review by experienced researchers in your field

- rapid publication on acceptance

- support for research data, including large and complex data types

- gold Open Access which fosters wider collaboration and increased citations

- maximum visibility for your research: over $100 \mathrm{M}$ website views per year

At BMC, research is always in progress.

Learn more biomedcentral.com/submissions 